\title{
Article \\ Quality of Grapes Grown Inside Paper Bags in Mediterranean Area
}

\author{
Antonino Pisciotta ${ }^{1, *(\mathbb{D})}$, Diego Planeta ${ }^{1}\left(\mathbb{D}\right.$, Simone Giacosa ${ }^{2, *} \mathbb{D}$, Maria Alessandra Paissoni ${ }^{2}$, \\ Rosario Di Lorenzo ${ }^{1}$ and Luca Rolle ${ }^{2}$ ID
}

1 Department of Agricultural, Food and Forest Sciences, University of Palermo, Viale delle Scienze, 11, 90128 Palermo, Italy; diego.planeta@unipa.it (D.P.); rosario.dilorenzo@unipa.it (R.D.L.)

2 Department of Agricultural, Forest and Food Sciences, University of Turin, Largo P. Braccini, 2, 10095 Grugliasco, Italy; mariaalessandra.paissoni@unito.it (M.A.P.); luca.rolle@unito.it (L.R.)

* Correspondence: antonino.pisciotta@unipa.it (A.P.); simone.giacosa@unito.it (S.G.); Tel.: +39-091-23861217 (A.P.)

Received: 14 April 2020; Accepted: 29 May 2020; Published: 2 June 2020

\begin{abstract}
The aim of this study was to evaluate the influence of paper bagging of grape bunches on the morphological, mechanical, and chemical characteristics of berries of three table grapes varieties as an environmentally-friendly technique for protecting clusters from biotic and abiotic agents. Clusters of Italia, Autumn Royal, and Regal Seedless grape cultivars were bagged and compared to a not-bagged control. Air temperature inside and outside the bags was monitored. Bunch weight and length, number of berries per bunch, berry longitudinal and transversal diameter, berry mass, number of seeds per berry (normal in size and aborted), soluble solid content, titratable acidity, and skin color by CIEL*a*b* parameters were determined on four points of each berry. Berries were evaluated using texture analysis, and the main texture profile analysis parameters were compared. The air temperatures around not-bagged clusters were slightly higher than inside the bags. In all the cultivars under evaluation, bagged bunches were heavier compared with not-bagged ones. In Autumn Royal and Regal Seedless, these differences were mainly owing to the higher number of berries and higher berry weight of the bagged bunches. Regarding mechanical properties, in seedless varieties, the bagging treatment increased berry hardness (related to the berry firmness) and decreased berry cohesiveness and resilience, whereas an opposite behavior was found in cv. Italia. Berry skin break force was lower in the bagging treatment in all the analyzed varieties, indicating a softer and easier-to-chew berry skin. The findings demonstrate that the bagging technique affected the three variety parameters to different extents. The main differences were found in the seedless varieties in terms of berry size and bunch characteristics. For all varieties, bagged bunches achieved the quality level required by the market, confirming the suitability of this technique. However, the bag industry is proposing many different bag types (differing in material, shape, color, and closing system); therefore, further studies are needed to obtain more complete and exhaustive technical information.
\end{abstract}

Keywords: table grape; paper bag; texture profile analysis; qualitative characteristics

\section{Introduction}

The table grape industry must increase its environmental sustainability. Italy is suffering a crisis owing to the overproduction of the main cultivated varieties (Vitis vinifera L. cvs. Italia, Red Globe, and Victoria), poor varietal innovation, fragmentation of supply chain, and high production costs [1]. To increase attractiveness, many growers have started to invest in the introduction of new varieties, innovative growing practices, and supporting the creation of producer organizations. In this context, the exclusivity of a product or technique having an environmentally-friendly approach is considered a 
useful tool [2]. Since 2002 in Sicily, and more recently in Apulia, the bunch-bagging technique has been studied and developed, leading to a new market product with low environmental impact.

Fruit bagging is an agricultural practice (or a physical protection technique) that helps to produce high quality fruit and is common in many countries such as Japan, China, and Spain [3-5]. This practice is commonly applied to several species, and the resulting products have higher visual quality through the promotion of peel coloration and reduction of fruit cracking and russeting. The bagging technique can modify the microenvironment to improve fruit development [6], which may result in several changes in internal fruit quality, as is the case for grapes produced under plastic coverings [7]. Bagging has been used extensively in several fruit crops with different aims, such as improvement of skin color or reduction of incidence of diseases, insect pests, mechanical damage, skin sunburn, agrochemical residues, and bird damage [5,8-13]. In previous studies, variable results have been reported regarding whether bags influence fruit quality; however, these different outcomes can be explained by different conditions, such as the climate, type of bags [14,15], fruit type, timing of bag placement [16], or duration of exposure to natural light following bag removal, as well as fruit- and cultivar-specific responses [6-10]. Pre-harvest bagging of fruit has been extensively used in fruit production, and although some fruits benefit from bagging, for others, this practice is not recommended. Certain fruits showed no significant change in fruit quality compared with their non-bagged control $[10,17,18]$. Bagging is practiced in Japan, Australia, and China for peach, apple, pear, grape, and loquat cultivations, which optimizes fruit quality by reducing physiological and pathological disorders and improving fruit coloration [19]. This improved appearance leads to an increase in product market value [11].

In table grapes, bagging leads to bunches more uniform in berry skin coloration [20], although several studies indicated that pre-harvest fruit bagging can both promote $[8,12,21]$ and inhibit fruit color development [22-25]. On the basis of these previous studies and the variable and sometimes contradictory results produced by the bagging technique on different fruits, the aim of this study was to evaluate the use of fruit bagging as a tool to produce high quality grapes on Sicily Island (Southern Italy), reducing the need for chemical treatments. We aimed to develop a bagging protocol that can be added to current table grape management practices in Mediterranean environmental climate conditions. The influence of bagging on the morphological, mechanical, and qualitative characteristics of berries was investigated in three of the most commonly cultivated table grape varieties in Sicily.

\section{Materials and Methods}

The trial was conducted in a biodynamic vineyard, located in Castrofilippo (Agrigento Province, Southern Italy $\left(37^{\circ} 19^{\prime} 43^{\prime \prime} \mathrm{N} ; 13^{\circ} 46^{\prime} 07^{\prime \prime} \mathrm{E}\right)$, during 2016 . Castrofilippo's climate is classified as warm and temperate. The winter months are rainier than in the summer months. This is considered a Csa climate (hot summer Mediterranean climate) according to the Köppen-Geiger classification. The average annual temperature is $15.4^{\circ} \mathrm{C}$ and the rainfall is around $461 \mathrm{~mm}$ per year. The lowest amount of rainfall occurs in July, with an average amount of $5 \mathrm{~mm}$. Most of the precipitation falls in October, averaging $72 \mathrm{~mm}$. The highest average temperatures occur in August $\left(23.7^{\circ} \mathrm{C}\right)$ and the lowest in January $\left(8.5^{\circ} \mathrm{C}\right)$ [26]. Three varieties were used for this study: Italia, Autumn Royal, and Regal Seedless. All three varieties were grafted onto Ruggeri 140 rootstock, trained to Tendone horizontal trellis, pruned with the Guyot system, leaving four canes and four spurs per plant, and drip irrigated with $3000 \mathrm{~m}^{3} /$ ha per season. Plant distances were $2.8 \times 2.8 \mathrm{~m}$. Three vines/variety per three randomized blocks were used as control and another three as bagged treatment (total of nine vines per variety). All bunches of the three varieties were bagged at pea size $(\mathrm{BBCH} 75)$ from the second week of June until the first week of July (vintage 2016). The bags remained on the vines for at least 90 days and they were not damaged during the season. The bags were composed of cellulose, $30 \times 40 \mathrm{~cm}$ in size, opened only on the top part, a grammage of approximately $55 \mathrm{~g} / \mathrm{m}^{2}( \pm 4 \%)$ (test method reference T410 om-98), and a thickness of $72 \mu \mathrm{m}( \pm 5 \mu \mathrm{m})$ (test method reference T411 om-97). Each bag was secured by tying it tightly around the fruit peduncle. After bagging, the air temperature inside and outside the bags was monitored using watchdog sensors (Spectrum Technologies, Aurora, IL, USA). Five sensors for each 
treatment were placed from 19 July to 17 October 2016. Hourly temperature data were recorded for each month. In the third week of August, the vineyards were protected from rain by covering them with polyethylene films.

Fifteen bunches for each treatment and variety were harvested (13 September cv. Regal and Autumn Royal; 10 December cv. Italia). The following parameters were measured for each bunch sample: length, weight, and number of berries per bunch. For each treatment and variety, on three replicates of 150 berries, the longitudinal (D.L.) and transversal diameter (D.T.), berry mass average and variability, number of seeds per berry (normal in size and aborted), and skin CIEL*a*b* color were determined at four points (one apical, one basal, and two equatorial faces) for each berry using a CR 410 Chroma Meter (Minolta Corp., Osaka, Japan). Instrumental color data are provided as CIEL*a*b coordinates, which define the color according to three-dimensional space. $\mathrm{L}^{*}$ indicates the lightness and is an approximate measurement of luminosity taking values within $0-100, a^{*}$ indicates the green-red chromaticity coordinates and has positive values for reddish colors and negative values for greenish colors, and $b^{*}$ is the blue-yellow chromaticity coordinates and has positive values for yellowish colors and negative values for bluish colors [27]. Standard illuminant $C$ was used as the reference [28,29].

The selected berries were crushed and the musts were used for the determination of soluble solid content (SSC), expressed as ${ }^{\circ}$ Brix, using a digital refractometer DBR 95 (XS Instruments, Carpi, Italy). Titratable acidity (TA) was determined according to the International Organisation of Vine and Wine, OIV-MA-AS313-01 method [30] using an automatic compact titration (Crison Instrument SA, Barcelona, Spain), and is expressed as $\mathrm{g} / \mathrm{L}$ of tartaric acid.

The measurements of the mechanical properties of berries were recorded for each cultivar, treatment, and mechanical test on a subset of 30 berries, directly taken with the attached pedicel from the whole bunches. For all texture analysis tests, the measurements were recorded using a Universal Testing Machine TA.XTplus Texture Analyzer (Stable Micro System, Godalming, Surrey, UK) equipped with a HDP/90 platform and a $5 \mathrm{~kg}$ load cell. Mechanical properties of the whole berry were evaluated using texture profile analysis (TPA) following the method reported by Letaief et al. [31]. Each whole berry was compressed at a speed of $1 \mathrm{~mm} / \mathrm{s}$ using a $35 \mathrm{~mm} \mathrm{P} / 35$ flat cylindrical probe (Stable Micro Systems) under a $25 \%$ berry deformation. Two compression cycles were conducted with a waiting time between the two cycles of $2 \mathrm{~s}$. The TPA parameters of berry hardness, cohesiveness, gumminess, springiness, chewiness, and resilience were calculated using Texture Exponent software (Stable Micro Systems). In detail, berry springiness was evaluated as the length $(\mathrm{mm})$ of the second compression $\left(d_{2}\right)$ [31]. Berry skin break force was evaluated by a puncture test, using a $\mathrm{P} / 2 \mathrm{~N}$ needle probe (Stable Micro Systems) and a speed of $1 \mathrm{~mm} / \mathrm{s}$ [32]. The berries were punctured in the equatorial portion to determine the berry skin break force $\left(\mathrm{F}_{\mathrm{sk}}\right.$ in $\left.\mathrm{N}\right)$ and berry skin break energy $\left(\mathrm{W}_{\mathrm{sk}}\right.$ in $\left.\mathrm{mJ}\right)$ [32]. Berry skin thickness $\left(\mathrm{Sp}_{\mathrm{sk}}\right.$ in $\mu \mathrm{m}$ ) was calculated as the distance between the point corresponding to a $\mathrm{P} / 22$ $\mathrm{mm}$ cylindrical probe (Stable Micro Systems) contact with the berry skin (trigger) and the platform base during a compression test [33], conducted at a speed of $0.2 \mathrm{~mm} / \mathrm{s}$.

Data were examined by one-way analysis of variance using SISTAT $10^{\circledR}$ software (Systat Software, Inc., San Jose, CA, USA). Mechanical properties data were evaluated using SPSS version 25.0 (IBM Corp., Armonk, NY, USA).

\section{Results}

On average, the air temperatures were slightly higher outside than inside the bag in July, August, and September $\left(0.36,0.23\right.$, and $0.15^{\circ} \mathrm{C}$, respectively), whereas in October, no differences were recorded $\left(-0.04{ }^{\circ} \mathrm{C}\right)$ (data not shown). This trend was particularly relevant if the differences in cumulative temperatures were considered. Outside the bag, higher accumulation was found with respect to inside the bag: $+8.7,+5.4$, and $+3.7^{\circ} \mathrm{C}$ in July, August, and September, respectively, whereas a reduction $\left(-1{ }^{\circ} \mathrm{C}\right)$ was found in October (data not shown). The different trends in temperatures in the period between August and October were probably the result of the effect of plastic covers in reducing solar radiation under the covering and, finally, differences between the outside and inside of the bag 
(Figure 1). In October, as the hours and intensity of sunlight decreased compared with the previous months, both the greenhouse effect due to the vineyard plastic covering and the insulating effect of the cluster bag were likely reduced, eliminating any difference in temperature between the outside and inside of the bag.
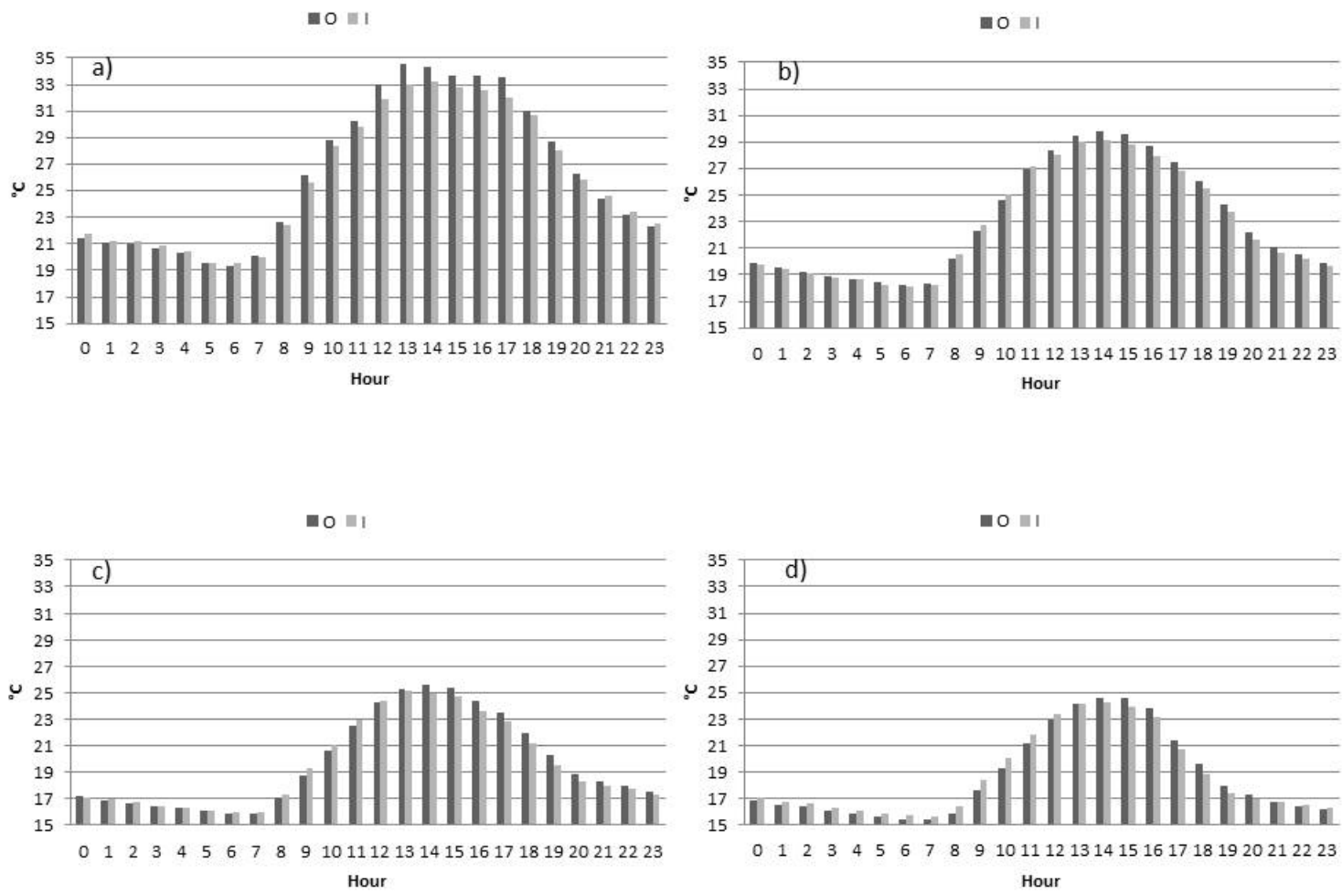

Figure 1. Hourly temperature $\left({ }^{\circ} \mathrm{C}\right.$ ) outside (O) and inside (I) the bag in (a) July, (b) August, (c) September, and (d) October.

From July to October, the daily external temperatures were higher than those inside the bag (Figure 1, Table 1). The night temperatures were higher inside the bag in July and October (Table 1).

Table 1. Day and night temperatures $\left({ }^{\circ} \mathrm{C}\right)$ inside and outside the bag.

\begin{tabular}{ccccccc}
\hline Month & & External & $\pm \boldsymbol{\sigma}$ & Internal & $\pm \boldsymbol{\sigma}$ & $\Delta \mathrm{E}-\mathbf{I}$ \\
\hline \multirow{2}{*}{ July } & Day & 30.87 & 3.7 & 30.04 & 3.4 & 0.83 \\
& Night & 21.64 & 2.1 & 21.75 & 2.0 & -0.11 \\
\hline \multirow{2}{*}{ August } & Day & 26.48 & 3.1 & 26.21 & 2.7 & 0.27 \\
& Night & 19.60 & 1.2 & 19.40 & 1.1 & 0.20 \\
\hline \multirow{2}{*}{ September } & Day & 22.45 & 2.8 & 22.23 & 2.6 & 0.22 \\
& Night & 16.98 & 1.0 & 16.88 & 0.8 & 0.10 \\
\hline \multirow{2}{*}{ October } & Day & 21.09 & 3.0 & 21.05 & 2.8 & 0.04 \\
& Night & 16.24 & 0.6 & 16.37 & 0.5 & -0.13 \\
\hline
\end{tabular}

$\Delta \mathrm{E}-\mathrm{I}=$ external and internal differences; $\pm \sigma=$ standard deviation.

In all varieties, the bagged bunches satisfied the quality requirements of the market [34]. In all cultivars, bagged bunches were heavier compared with the non-bagged control. In Autumn Royal and Regal Seedless, these differences were mainly owing to the higher number of berries in the bagged bunches (33\% and 20\% more berries per bunch for the two varieties, respectively; $p \leq 0.01$ and $p \leq 0.05$, respectively) as well as to a higher berry weight $(p \leq 0.05)$. Cv. Italia showed the same trend in bunch 
weight and number of berries per bunch, but the differences were limited (Table 2). In Italia cv., the paper bag produced an increase in the number of seeds aborted per berry $(p \leq 0.05$, Table 2).

Table 2. Fruit quality parameters for bagged (B) and not bagged (NB) grapes: bunch mass (g), berry number, berry mass $(\mathrm{g})$, rachis length $(\mathrm{cm})$, compactness index, shape (longitudinal and transversal diameter, DL/DT), percentage of aborted seeds, SSC (soluble solid content, ${ }^{\circ}$ Brix), titratable acidity (g/L), and soluble solid content/titratable acidity ratio (SSC/TA).

\begin{tabular}{ccccccccccc}
\hline & \multicolumn{3}{c}{ Autumn Royal } & \multicolumn{4}{c}{ Regal Seedless } & \multicolumn{3}{c}{ Italia } \\
\hline Parameter & u.m. & B & NB & Sig. & B & NB & Sig. & B & NB & Sig. \\
\hline Bunch mass & $\mathrm{g}$ & 965.40 & 661.24 & $* *$ & 638.00 & 439.98 & $* *$ & 969.50 & 863.09 & $* *$ \\
Berry number & $n$ & 124.49 & 93.60 & $* *$ & 114.48 & 95.40 & $*$ & 131.00 & 111.40 & $* *$ \\
Berry mass & $\mathrm{g}$ & 8.09 & 7.02 & $*$ & 5.50 & 4.83 & $*$ & 7.66 & 7.95 & n.s. \\
Rachis Length & $\mathrm{cm}$ & 25.10 & 29.30 & $*$ & 32.50 & 28.10 & n.s. & 26.70 & 26.50 & n.s. \\
Compactness Index & & 4.96 & 3.19 & $* *$ & 3.52 & 3.40 & n.s. & 4.91 & 4.20 & $*$ \\
Shape DL/DT & & 1.29 & 1.24 & n.s. & 1.43 & 1.49 & n.s. & 1.24 & 1.23 & n.s. \\
Aborted seed & $\%$ & 100 & 100 & & 100 & 100 & & 43 & 9 & $*$ \\
Soluble Solids & ${ }^{\circ}$ Brix & 15.3 & 15.5 & n.s. & 19.0 & 16.3 & $*$ & 16.9 & 17.2 & n.s. \\
Content & $\mathrm{g} / \mathrm{L}$ & 3.1 & 3.1 & n.s. & 3.9 & 3.7 & n.s. & 4.4 & 6.1 & $*$ \\
Titratable acidity & & 39.5 & 40.0 & n.s. & 40.0 & 35.2 & $*$ & 30.7 & 22.5 & $*$ \\
SSC/TA & & & & & & & & & & \\
\end{tabular}

Sig. ${ }^{*}, *$, and n.s. indicate significant differences at $p \leq 0.05,0.01$, and not significant differences, respectively, among grape treatments (bagged vs. not bagged); u.m. = unit of measurement.

Owing to the higher number of berries per bunch in bagged grapes, an increased bunch compactness (number of berries/rachis length) was found, especially in cv. Autumn Royal ( $p \leq$ $0.01,4.96$ and 3.19 for bagged and not bagged grapes, respectively; Table 2).

According to OIV resolution VITI 1/2008 [35], table grapes are considered ripe when SSC $\geq 16$ ${ }^{\circ}$ Brix. For SSC $<16{ }^{\circ}$ Brix and SSC $>12.5^{\circ}$ Brix, table grapes are considered ripe when the maturity index (SSC/TA) is $>20$ [35]. The berry must composition reported in Table 2 shows that all samples studied can be considered ripe. In particular, in cv. Autumn Royal, bagged bunches did not differ from those not bagged in terms of soluble solids content and sugar/acidity ratio, whereas the use of bags in Regal Seedless grapes significantly increased the soluble solids content $\left(19.0\right.$ and $16.3^{\circ}$ Brix for bagged and not bagged grapes, respectively; $p \leq 0.05$ ). In Italia grapes, a consistent difference was found in titratable acidity ( 4.4 vs. $6.1 \mathrm{~g} / \mathrm{L}$ for bagged and not bagged grapes, respectively; $p \leq 0.05$ ) and maturity index (30.7 vs. 22.5 for bagged and not bagged grapes, respectively; $p \leq 0.05$ ), probably owing to the longer period that bunches spent inside the bag (Table 2).

Regarding CIEL*a* $b^{*}$ parameters, in Autumn Royal grapes, all color coordinates were statistically affected by the paper bags $(p<0.05)$. The bagged grapes presented higher values of lightness $\left(L^{*}\right)$, redness (positive $a^{*}$ ), and yellowness (positive $b^{*}$ ). Therefore, the not bagged grapes were darker (27.4), less red (5.2), and more blue (0.1) compared with the bagged samples $\left(\mathrm{L}^{*}=30.4 ; \mathrm{a}^{*}=5.6 ; \mathrm{b}^{*}=1.1\right)$. The use of paper bags in white varieties (Italia and Regal Seedless) did not significantly affect $b^{*}$ in Regal and $\mathrm{L}^{*}$ and $\mathrm{a}^{*}$ in Italia; therefore, non-bagged Regal Seedless grapes were darker $\left(\mathrm{L}^{*}=42.2\right.$ and 44.3 for not-bagged and bagged grapes, respectively). These results lead us to suggest that the bagging technique slightly delayed the phenolic ripening process of black cultivar Autumn Royal, whereas any evident color effect was produced in white varieties (Table 3). Bagging reduced the coefficient of variation of $b^{*}$ in red grapes (Autumn Royal; Table 4). 
Table 3. Skin CIEL* $\mathrm{a}^{*} \mathrm{~b}^{*}$ color parameters, $\mathrm{L}^{*}$ (Lightness), $\mathrm{a}^{*}$ (red/green coordinate), and $\mathrm{b}^{*}$ (yellow/blue coordinate), of bagged (B) and not bagged (NB) berry skin of the three table grape varieties.

\begin{tabular}{cccccccccc}
\hline & \multicolumn{3}{c}{ Autumn Royal } & \multicolumn{3}{c}{ Regal Seedless } & \multicolumn{3}{c}{ Italia } \\
\hline Parameter & B & NB & & B & NB & & B & NB & \\
\hline $\mathrm{L}^{*}$ & 30.37 & 27.42 & $*$ & 44.28 & 42.23 & $*$ & 37.84 & 37.72 & n.s. \\
$\mathrm{a}^{*}$ & 5.65 & 5.20 & $*$ & -6.11 & -6.77 & $*$ & -4.40 & -4.39 & n.s. \\
$\mathrm{b}^{*}$ & 1.08 & 0.11 & $*$ & 18.95 & 18.47 & n.s. & 11.62 & 10.97 & $*$ \\
\hline
\end{tabular}

Note: ${ }^{*}$, and n.s. indicate significant differences at $p \leq 0.05,0.01$, and not significant differences, respectively, among grape treatments (bagged vs. not bagged).

Table 4. Coefficient of variation ( \pm c.v. \%) of skin CIEL* $\mathrm{a}^{*} \mathrm{~b}^{*}$ color parameters, $\mathrm{L}^{*}$ (Lightness), $\mathrm{a}^{*}($ red/green coordinate), and $b^{*}$ (yellow/blue coordinate), of bagged (B) and not bagged (NB) berry skin of the three table grape varieties.

\begin{tabular}{ccccccc}
\hline & \multicolumn{2}{c}{ Autumn Royal } & \multicolumn{2}{c}{ Regal Seedless } & \multicolumn{2}{c}{ Italia } \\
\hline Parameter & B & NB & B & NB & B & NB \\
\hline $\mathrm{L}^{*}$ & 13.4 & 12.2 & 9.7 & 10.2 & 5.8 & 6.0 \\
$\mathrm{a}^{*}$ & 44.5 & 51.8 & 25.9 & 25.7 & 28.2 & 27.5 \\
$\mathrm{~b}^{*}$ & 249.0 & 1537.0 & 22.3 & 21.9 & 19.3 & 18.4 \\
\hline
\end{tabular}

The mechanical properties of bagged and control (not bagged) grape berries were also evaluated. The berry skin break force of all bagged berries were lower compared with the control treatment; however, only in the case of white grapes (Regal and Italia) were the differences induced by the treatment significant $(p \leq 0.01$; Table 5). No significant $(p>0.05)$ influence of the treatment was found on the berry skin thickness parameter. Whole-berry texture profile analysis resulted in six parameters, three of which showed a significant $(p \leq 0.05)$ influence of the paper bag treatment: berry hardness, berry cohesiveness, and berry resilience. However, the resulting data showed a different behavior depending on the seed content of these varieties: berry skin hardness decreased for the bagged grapes of seedless varieties, whereas the opposite trend was found for the Italia seeded cultivar. Berry cohesiveness (strength of internal bonds composing the berry body) and berry resilience (berry ability to regain original position) [36] were affected by this trait (Table 5).

Table 5. Mechanical properties of bagged (B) and not bagged (NB) berries at harvest as induced by the treatment.

\begin{tabular}{cccccccccccc}
\hline & \multicolumn{4}{c}{ Autumn Royal } & \multicolumn{3}{c}{ Regal Seedless } & \multicolumn{3}{c}{ Italia } \\
\hline Parameter & u.m. & B & NB & Sig. & B & NB & Sig. & B & NB & Sig. \\
\hline Berry skin break force $\left(\mathrm{F}_{\text {sk }}\right)$ & $\mathrm{N}$ & 0.556 & 0.600 & n.s. & 0.911 & 1.039 & $* * *$ & 0.755 & 0.900 & $* *$ \\
Berry skin break energy $\left(\mathrm{W}_{\text {sk }}\right)$ & $\mathrm{mJ}$ & 0.159 & 0.176 & n.s. & 0.817 & 0.881 & n.s. & 0.621 & 0.742 & n.s. \\
Berry skin thickness $\left(\mathrm{Sp}_{\mathrm{sk}}\right)$ & $\mathrm{\mu m}$ & 205 & 196 & n.s. & 236 & 206 & n.s. & 207 & 235 & n.s. \\
Berry hardness & $\mathrm{N}$ & 37.6 & 32.1 & $*$ & 19.2 & 16.2 & $*$ & 12.8 & 16.5 & $*$ \\
Berry cohesiveness & - & 0.426 & 0.471 & $*$ & 0.460 & 0.527 & $* *$ & 0.497 & 0.446 & $* *$ \\
Berry gumminess & $\mathrm{N}$ & 15.92 & 15.08 & n.s. & 8.74 & 8.38 & n.s. & 6.00 & 7.01 & $*$ \\
Berry springiness $\left(\right.$ as $\left.\mathrm{d}_{2}\right)$ & $\mathrm{mm}$ & 3.75 & 3.75 & n.s. & 3.05 & 3.00 & n.s. & 4.19 & 3.81 & $* * *$ \\
Berry chewiness & $\mathrm{mJ}$ & 58.9 & 57.7 & n.s. & 26.9 & 25.3 & n.s. & 24.9 & 26.4 & n.s. \\
Berry resilience & - & 0.262 & 0.271 & $*$ & 0.224 & 0.263 & $* *$ & 0.236 & 0.206 & $* *$ \\
\hline
\end{tabular}

Sig.: ${ }^{*}, * * * *$, and n.s. indicate significant differences at $p \leq 0.05,0.01$, and 0.001 , and not significant differences, respectively, among grape treatments (bagged vs. not bagged); u.m. = unit of measurement.

\section{Discussion}

Berry size is an important parameter for growers owing to its attractiveness to consumers. In table grapes varieties, berry size is related to different physicochemical characteristics [37]. After setting, the fruit grows slowly and increases in size up to maturity. The bagging technique has been extensively used in many fruits, and different effects on fruit size have been found. In our case, covering grapes 
with a paper bag at the pea size developmental stage influenced both their growth and size. In bagged grapes, the highest mass was more owing to the berry size than to the number of berries per bunch. Studies on the effects of fruit bagging on fruit size and weight showed contradictory results, and these contrasting outcomes may be because of the use of different bag types, fruit age at bagging, and climatic conditions [12,38-43]. Positive effects of bagging on fruit growth, size, and weight have been reported in carambola [44], mango [45,46], longan fruit [47], date palm [48], and olive [43]. Pre-harvest fruit bagging was reported to reduce fruit size and weight in loquat [13], pears [49], pomegranate [50], and apple [51]. For certain fruits, there was no significant change in size compared with their unbagged control, for instance, in banana $[52,53]$ and pear $[8,54]$.

The practice of pre-harvest bagging is used in several fruit crops to delay ripening [55], to reduce splitting and mechanical damage [12], and to improve marketability [56]. Contradictory effects reported on fruit maturity likely reflect differences in the type of bag used, fruit stage when bagged, and/or fruit- and cultivar-specific response [8]. In banana [53,57], litchi fruit [58], peach [15,59], and date palms [48,60], researchers described the bagging practice as an enhancer of fruit maturity, accelerating the ripeness. In contrast, bagging did not affect fruit maturity in apple [61], whereas Signes et al. [20] reported that pre-harvest bagging delayed ripening in table grapes cv. Perla. Little or no effect was reported in 40 varieties of Vitis vinifera [62].

In our study, differences in sugar accumulation were found only in cv. Regal Seedless, and differences in titratable acidity only in cv. Italia. The slightly lower content of sugars and the simultaneously lower content of organic acids in bagged Italia grapes compared with unbagged grapes imply a delay in the ripening process caused by the implementation of pre-harvest bagging.

One of the main concerns for grape growers using fruit bags is how this practice may affect fruit color, as different bag materials can partially exclude light from reaching the fruit. Several research studies examined the effect of bagging in different species and indicated that pre-harvest fruit bagging can both promote or inhibit fruit color development depending on the bagging conditions. Studies reported that bagging improves fruit color by increasing the anthocyanin content in litchi [12,21,63], apple [16,61,64-66], pear [8,67,68], mango [46,69], and sweet orange [70]. In our experimental conditions, bags increased color uniformity and reduced the color variation in Autumn Royal (Table 3), even if a variability in terms of whole berry anthocyanins was previously reported [71]. Signes et al. [20] reported that pre-harvest bagging with cellulose bags increased the uniformity of color development in the black grape variety Perla, and Hofman et al. [10] reported similar results in mango fruits. However, the effect of fruit bagging more often inhibits than promotes color development [24]. The effect on color depends on several factors including the stage of fruit development when bagged, the bagging date, the kind of bag used, the date of bag removal, and the climatic conditions of the area $[8,61,72,73]$. Color was inhibited in plum fruit [23], Red Fuji apple [74,75], and pear [54]. The color space system used in this study (CIEL* $a^{*} b^{*}$ ) is one of the most popular methods for objectively measuring color, especially in the fruit production and food industry. However, the results obtained in this study using this color space showed no unequivocal results (Table 2). A shared higher color lightness in bagged grapes was found [20], especially in Autumn Royal and Regal $(p \leq 0.05)$ and, to a lesser extent, in cv. Italia, although this difference was not significant $(p>0.05)$. Reduced color $\left(b^{*}\right)$ in Autumn Royal and Italia bagged grapes may be the result of modification of the light, atmosphere, and temperature [76,77] inside the bag, leading to a reduced anthocyanin accumulation [8,78]. Regardless, a positive bag effect may occur during late season on qualitative and sanitary parameters. In the late season (from October onward), bagging seems to create warmer conditions, which is useful for improving the quality of autumn-winter late harvest grapes (Figure 1).

Berry texture parameters may be evaluated using a wide number of berry portions: skin, flesh (or pulp), and seeds, each of them contributing, to different extents, to the consistency and elasticity of a berry. These properties are important for consumer acceptance and preference because, among others, they determine the tactile sensory characteristics of the product [79-83]. The use of instrumental 
mechanical properties as objective analysis may also permit the classification of table grapes in accordance with the OIV ampelographic descriptors [84].

Considering the whole berry measurements, texture profile analysis is one of the most effective general tools used to objectively evaluate the comprehensive set of sensory-related properties of a food [85]. TPA consists of a double compression of a food to a given deformation percentage, obtaining a characteristic force-distance curve that allows the evaluation of properties like berry hardness, cohesiveness, and chewiness. In our experimental conditions, the paper bagging treatment significantly $(p \leq 0.05)$ influenced berry hardness (a parameter that some authors call berry firmness), [86-88] and cohesiveness in all varieties considered. However, the presence of the seeds distinguished the outcome of the treatment: in seedless varieties (Autumn Royal and Regal Seedless), the bagging treatment positively increased berry hardness and decreased berry cohesiveness, whereas the opposite was found in Italia grapes. It is unclear how the presence of the seeds influenced this behavior. Seeds contribute to whole-berry TPA parameters because they are present in seeded varieties that were re-evaluated with this method [81]; however, their presence is enclosed by the flesh, possibly limiting their contribution to the obtained numerical TPA values. Therefore, the different behaviors for these TPA parameters depending on the presence of the seeds are possibly related to other factors such as different responses by the plant.

The concomitant variations in berry hardness and berry cohesiveness had a particular effect on other TPA parameters that are calculated on the interaction between them, namely berry gumminess and berry chewiness [31]. Berry gumminess was significantly different only in the case of cv. Italia $(p \leq 0.05)$, whereas no significant effects on berry chewiness (calculated with the influence of berry springiness) were found, effectively resulting in a compensating effect of the berry hardness and cohesiveness parameters when combined.

Berry skin break force is one of the key parameters used for the evaluation of the mechanical characteristics of berry skin [81]. The ability to measure the resistance to penetration of a given berry skin could be related to a sensory resistance to chewing. The paper bag treatment influenced this parameter, with significant decreases $(p \leq 0.01)$ in two out of the three varieties tested. Therefore, we hypothesize that the outcome of the treatment is producing an easier-to-be-chewed berry skin, which is a positive trait for the table grape industry.

In berry skin evaluation, the thickness parameter is another important indicator of acceptance. This parameter is traditionally evaluated by histological methods that are generally time-consuming and require special reagents and procedures. As such, the use of faster methods such as the thickness evaluation by texture analysis simplifies and quickens the process, enabling the analysis of a large number of berries for each sample, producing results comparable with the histological assessments [29]. Berry skin thickness was found to be a negative characteristic in the consumer acceptance of Muscadine grapes (Vitis rotundifolia) [89], which is highly related to bitterness and astringency attributes in table grapes [79]. In this study, the average values for skin thickness ranged between 196 and $236 \mu \mathrm{m}$ (Table 5), accounting for differences between bagged and unbagged treatments of $+11,+30$, and -28 $\mu \mathrm{m}$ for Autumn Royal, Regal Seedless, and Italia cultivars, respectively. Owing to the high standard deviation typical of this instrumental parameter, no significant differences $(p>0.05)$ in berry skin thickness were found between bagged and control (not bagged) grapes.

\section{Conclusions}

The bagging technique is considered a valuable tool for substantially reducing or avoiding pesticide residues on fruit, as well as limiting damage during ripening. As such, the benefits in terms of sustainability using bags are priceless, even considering the cost of labor and bags necessary to apply this technique in the field. However, bagging may modify the quality parameters of table grapes to different extents. In our study, this practice produced different results from both qualitative and quantitative viewpoints, mainly depending on the variety. The main differences were found in the seedless varieties in terms of berry size and bunch characteristics, which we examined over one year. 
Growers have always monitored the color parameter, which can be influenced by extrinsic factors from the use of bags. In our results, color was modified by paper bagging depending on the variety.

In all the varieties studied, the bagged bunches achieved the quality level required by the market. The bag industry is producing many different bag types (material, shape, color, and closing system); therefore, further studies may be required to evaluate the suitability of these different bags in terms of influence on the quality of table grapes.

Author Contributions: A.P. wrote the first draft of the manuscript and followed the agronomical and physiological measurements, coordinated the whole project, provided the intellectual input, and set up the experiment. R.D.L., D.P., S.G., M.A.P., and L.R. were involved in data analysis, data interpretation, review, and editing the manuscript. All authors have read and agreed to the published version of the manuscript.

Funding: This research received no external funding.

Acknowledgments: The authors thank Golden Grapes Company (Via E. Fermi 36, Naro, Italy) and their technicians for assistance and technical advice.

Conflicts of Interest: The authors declare no conflict of interest.

\section{References}

1. Di Lorenzo, R. Appello per tornare competitivi: Cambiamento strategico e colturale. Frutticoltura 2020, 1, 4-6.

2. Di Lorenzo, R.; Pisciotta, A.; Santamaria, P.; Scariot, V. From soil to soil-less in horticulture: Quality and typicity. Ital. J. Agron. 2013, 8, 255-260. [CrossRef]

3. Faci, J.; Medina, E.; Martínez-Cob, A.; Alonso, J. Fruit yield and quality response of a late season peach orchard to different irrigation regimes in a semi-arid environment. Agric. Water Manag. 2014, 143, $102-112$. [CrossRef]

4. Jia, H.; Araki, A.; Okamoto, G. Influence of fruit bagging on aroma volatiles and skin coloration of 'Hakuho' peach (Prunus persica Batsch). Postharvest Biol. Technol. 2005, 35, 61-68. [CrossRef]

5. Kitagawa, H.; Manabe, K.; Esguerra, E. Bagging of fruit on the tree to control disease. Front. Trop. Fruit Res. 1992, 321, 871-875. [CrossRef]

6. Fan, X.; Mattheis, J.P. Bagging 'Fuji' apples during fruit development affects color development and storage quality. HortScience 1998, 33, 1235-1238. [CrossRef]

7. Novello, V.; de Palma, L.; Tarricone, L.; Vox, G. Effects of Different sheet coverings on microclimate and berry ripening of table grape cv. 'Matilde'. J. Int. Sci. Vigne Vin 2000, 34, 49-55. [CrossRef]

8. Amarante, C.; Banks, N.H.; Max, S. Effect of preharvest bagging on fruit quality and postharvest physiology of pears (Pyrus communis). N. Z. J. Crop Hortic. Sci. 2002, 30, 99-107. [CrossRef]

9. Bentley, W.J.; Viveros, M. Brown-bagging 'Granny Smith' apples on trees stops codling moth damage. Calif. Agric. 1992, 46, 30-32. [CrossRef]

10. Hofman, P.J.; Smith, L.G.; Joyce, D.C.; Johnson, G.I.; Meiburg, G.F. Bagging of mango (Mangifera indica cv. 'Keitt') fruit influences fruit quality and mineral composition. Postharvest Biol. Technol. 1997, 12, 83-91. [CrossRef]

11. Joyce, D.C.; Beasley, D.R.; Shorter, A.J. Effect of pre-harvest bagging on fruit calcium levels, and storage and ripening characteristics of 'Sensation' mangoes. Aust. J. Exp. Agric. 1997, 37, 383-389.

12. Tyas, J.A.; Hofman, P.J.; Underhill, S.J.R.; Bell, K.L. Fruit canopy position and panicle bagging affects yield and quality of 'Tai So' lychee. Sci. Hortic. 1998, 72, 203-213. [CrossRef]

13. Xu, H.; Chen, J.; Xie, M. Effect of different light transmittance paper bags on fruit quality and antioxidant capacity in loquat. J. Sci. Food Agric. 2010, 90, 1783-1788. [CrossRef] [PubMed]

14. Coelho, L.R.; Leonel, S.; Crocomo, W.B.; Labinas, A.M. Evaluation of different bags in peach crop. Revista Brasileira De Fruticultura 2008, 30, 822-826. [CrossRef]

15. Kim, Y.H.; Kim, H.H.; Youn, C.K.; Kweon, S.J.; Jung, H.J.; Lee, C.H. Effects of bagging material on fruit coloration and quality of 'Janghowon Hwangdo' peach. Acta Hortic. 2008, 772, 81-86.

16. Sharma, R.R.; Pal, R.K.; Asrey, R.; Sagar, V.R.; Dhiman, M.R.; Rana, M.R. Pre-harvest fruit bagging influences fruit color and quality of apple cv. Delicious. Agric. Sci. 2013, 4, 443-448. [CrossRef] 
17. Xin, H.M.; Zang, X.H. Influence of bagging on the fruit inclusion and endogenous ormones of "Yali" Pear variety. J. Fruit Sci. 2003, 20, 233-235.

18. Perring, M.A.; Clijsters, H. The chemical composition and storage characteristics of apples grown in black cloth bags. Qual. Plantarum. 1974, 23, 379-393. [CrossRef]

19. Amarante, C.; Banks, N.H.; Max, S. Pre-harvest bagging improves packout and fruit quality of pears (Pyrus communis). N. Z. J. Crop Hortic. Sci. 2002, 30, 93-98. [CrossRef]

20. Signes, A.J.; Burlo, F.; Martinez-Sanchez, F.; Carbonell-Barrachina, A.A. Effects of preharvest bagging on quality of black table grapes. World J. Agric. Sci. 2007, 3, 32-38.

21. Chen, D.; Li, P. Effect of bagging on fruit colouration of litchi (Litchi chinensis Sonn. cv. Feizixiao). J. South China Agric. Univ. 1999, 20, 65-69.

22. Kwan, K.D.; Soo, C.D.; Sik, K.E.; Hyuan, H.K.; Ho, L.K.; Sik, K.K.; Cheol, L.K. Fruit quality of Yuzu (Citrus junos L.) as influenced by bagging time and materials of bagging treatment. J. Korean Soc. Hortic. Sci. 2000, 41, 190-193.

23. Murray, X.J.; Holcroft, D.M.; Cook, N.C.; Wand, S.J. Postharvest quality of 'Laetitia' and 'Songold' (Prunus salicina Lindell) plums as affected by pre-harvest shading treatments. Postharvest Biol. Technol. 2005, 37, 81-92. [CrossRef]

24. Proctor, J.T.A.; Lougheed, E.C. The effect of covering apples during development. Hort. Sci. 1976, 11, 108-109.

25. Sharma, R.R.; Reddy, S.; Jhalegar, M. Pre-harvest fruit bagging: A useful approach for plant protection and improved post-harvest fruit quality-A review. J. Hortic. Sci. Biotechnol. 2014, 89, 101-113. [CrossRef]

26. Servizio Informativo Agrometeorologico Siciliano, 2017. Assessorato Regionale delle Risorse Agricole e Alimentari. Available online: www.sias.regione.sicilia.it (accessed on July 2017).

27. Minolta. Precise Color Communication. Color Control from Feeling to Instrumentation; Minolta, Co. Ltd.: Osaka, Japan, 1994.

28. Rolle, L.; Guidoni, S. Color and anthocyanin evaluation of red winegrapes by CIE $\mathrm{L}^{*}, \mathrm{a}^{*}, \mathrm{~b}^{*}$ parameters. J. Int. Sci. Vigne Vin 2007, 41, 193-201. [CrossRef]

29. Rolle, L.; Giordano, M.; Giacosa, S.; Vincenzi, S.; Río Segade, S.; Torchio, F.; Perrone, B.; Gerbi, V. CIEL*a*b* parameters of white dehydrated grapes as quality markers according to chemical composition, volatile profile and mechanical properties. Anal. Chim. Acta 2012, 732, 105-113. [CrossRef]

30. Compendium of International Methods of Analysis of Wines and Musts; International Organisation of Vine and Wine: Paris, France, 2016.

31. Letaief, H.; Rolle, L.; Gerbi, V. Mechanical behavior of winegrapes under compression tests. Am. J. Enol. Vitic. 2008, 59, 323-329.

32. Letaief, H.; Rolle, L.; Zeppa, G.; Gerbi, V. Assessment of grape skin hardness by a puncture test. J. Sci. Food Agric. 2008, 88, 1567-1575. [CrossRef]

33. Battista, F.; Tomasi, D.; Porro, D.; Caicci, F.; Giacosa, S.; Rolle, L. Winegrape berry skin thickness determination: Comparison between histological observation and texture analysis determination. Ital. J. Food Sci. 2015, 27, 8-13.

34. COMMISSION IMPLEMENTING REGULATION (EU) No 543/2011 of 7 June 2011laying down detailed rules for the application of Council Regulation (EC) No 1234/2007 in respect of the fruit and vegetables and processed fruit and vegetables sectors. CONSOLIDATED TEXT: Annex I; Part 9 of Part B MARKETING STANDARD FOR TABLE GRAPES.

35. OIV. OIV Standard on Minimum Maturity Requirements for Table Grapes; Resolution VITI 1/2008; Organisation Internationale de la Vigne et du Vin: Paris, France, 2008.

36. Río Segade, S.; Orriols, I.; Giacosa, S.; Rolle, L. Instrumental texture analysis parameters as winegrapes varietal markers and ripeness predictors. Int. J. Food Prop. 2011, 14, 1318-1329. [CrossRef]

37. Rolle, L.; Torchio, F.; Giacosa, S.; Río Segade, S. Berry density and size as factors related to the physicochemical characteristics of Muscat Hamburg table grapes (Vitis vinifera L.). Food Chem. 2015, 173, 105-113. [CrossRef] [PubMed]

38. Chen, C.; Zhang, D.; Wang, Y.; Li, P.; Ma, F. Effects of fruit bagging on the contents of phenolic compounds in the peel and flesh of 'Golden Delicious', 'Red Delicious', and 'Royal Gala' apples. Sci. Hortic. 2012, 142, 68-73. [CrossRef]

39. He, W.H.; Wang, Q.; Zhang, S.Y.; Huang, X.G.; Li, S.H.; Huang, C.X. Effects of bagging and calcium spraying on mineral nutrient and quality of 'Suli' pear variety. J. Fruit Sci. 2003, 20, 18-21. 
40. Huang, C.H.; Chai, M.L.; Pan, Z.M.; Yu, B.; Jiang, Z.M.; Hu, J.L.; Teng, Y.W. Effects of bagging on fruit skin features and quality of 'Cuiguan' pear cultivar. J. Fruit Sci. 2007, 24, 747-751.

41. Wang, S.M.; Gao, H.J.; Zhang, X.B. Effects of bagging on pigment, sugar and acid development in 'Red Fuji' apple fruit. Acta Hortic. Sin. 2002, 29, 263-265.

42. Zhen, G.H.; Liao, W.C.; Fan, W.M. Effects of bag materials and bagging dates on loquat fruits. Fujian Fruits 2000, 114, 1-4.

43. Zhou, J.; Zhong, G.; Lin, Z.; Xu, H.L. The effects of bagging on fresh fruit quality of Canarium album. J. Food. Agric. Environ. 2012, 10, 505-508.

44. Xu, C.X.; Chen, H.B.; Huang, R.Y.; He, Y.J. Effects of bagging on fruit growth and quality of carambola. Acta Hortic. 2008, 773, 195-200. [CrossRef]

45. Chonhenchob, V.; Kamhangwong, D.; Kruenate, J.; Khongrat, K.; Tangchantra, N.; Wichai, U.; Singh, S.P. Preharvest bagging with wavelength-selective materials enhances development and quality of mango (Mangifera indica L.) cv. Nam Dok Mai \#4. J. Sci. Food Agric. 2011, 91, 664-671.

46. Watanawan, A.; Watanawan, C.; Jarunate, J. Bagging 'Nam Dok Mai \#4' mango during development affects colour and fruit quality. Acta Hortic. 2008, 787, 325-328.

47. Yang, W.; Zhu, X.; Bu, J.; Hu, G.; Wang, H.; Huang, X. Effects of bagging on fruit development and quality in cross-winter off-season longan. Sci. Hortic. 2009, 120, 194-200. [CrossRef]

48. Harhash, M.M.; Al-Obeed, R.S. Effect of bunch bagging colour on yield and fruit quality of date palm. Am. Eurasian J. Agric. Environ. Sci. 2010, 7, 312-319.

49. Hudima, M.; Stamper, F. Effect of fruit bagging on quality of 'Conference' pear (Pyrus communis L.). Eur. J. Hortic. Sci. 2011, 76, 410-414.

50. Hussein, A.; Abd-El-Rahman, A.; Ahmed, R. Effectiveness of fruit bagging on yield and fruit quality of pomegranate (Punica granatum L). Ann. Agric. Sci. 1994, 32, 949-957.

51. Arakawa, O.; Uematsu, N.; Nakajima, H. Effect of bagging on fruit quality in apples. Bull. Fac. Agric. Hirosaki Univ. 1994, 57, 25-32.

52. Muchui, M.N.; Mathooko, F.M.; Njoroge, C.K.; Kahangi, E.M.; Onyango, C.A.; Kimani, E.M. Effect of perforated blue polyethylene bunch covers on selected postharvest quality parameters of tissue-cultured bananas (Musa spp.) cv. Williams in Central Kenya. J. Stored Prod. Postharvest Res. 2010, 1, $29-41$.

53. Rodrigues, M.G.V.; Souto, R.F.; Menegucci, J.L.P. Influence of polyethylene banana bunch cover for irrigated banana tree in the North of Minas Gerais state. Rev. Bras. De Frutic. 2001, 23, 559-562. [CrossRef]

54. Hudima, M.; Stamper, F. Bagging of 'Concorde' pears (Pyrus communis L.) influences fruit quality. Acta Hortic. 2011, 909, 625-630. [CrossRef]

55. Scott, K.J.; Wills, R.B.H.; Rippon, L.E. The use of sealed polyethylene bunch covers during growth as a retardant to the ripening of bananas. Trop. Agric. 1971, 48, 163-165.

56. Katagiri, T.; Satoh, Y.; Fukuda, T.; Kataoka, I. Improving marketability of 'Fuyu' persimmon fruit by bagging culture. Acta Hortic. 2003, 601, 213-217. [CrossRef]

57. Stover, R.H.; Simmonds, N.W. Bananas, 3rd ed.; Tropical Agriculture Series; Longman Scientific and Technical: Harlow, UK, 1987; p. 468.

58. Debnath, S.; Mitra, S.K. Panicle bagging for maturity regulation, quality improvement and fruit borer management in litchi (Litchi chinensis). Acta Hortic. 2008, 773, 201-208. [CrossRef]

59. Wang, Y.J.; Yang, C.X.; Liu, C.Y.; Xu, M.; Li, S.H.; Yang, L.; Wang, Y.N. Effects of bagging on volatiles and polyphenols in 'Wanmi' peaches during endocarp hardening and final fruit rapid growth stages. J. Food Sci. 2010, 75, 455-460. [CrossRef]

60. Kassem, H.A.; Omar, A.K.H.; Ahmed, M.A. Response of 'Zaghloul' date palm productivity, ripening and quality to different polyethylene bagging treatments. Am. Eurasian J. Agric. Environ. Sci. 2011, 11, 616-621.

61. Ju, Z. Fruit bagging, a useful method for studying anthocyanin synthesis and gene expression in apples. Sci. Hortic. 1998, 77, 155-164. [CrossRef]

62. Weaver, R.J.; Mccune, S.B. Influence of Light on Color Development in Vitis Vinifera Grapes. American J. Enol. Vitic. 1960, 11, 179-184.

63. Hu, G.; Chen, D.; Li, P.; Ouyang, R.; Gao, F.; Wang, W.; Dong, J. Effects of bagging on fruit colouration and phenylalanine ammonia lyase and polyphenol oxidase in 'Feizixiao' litchi. Acta Hortic. 2001, 558, $273-278$. [CrossRef] 
64. Liu, Y.; Zhang, X.; Zhao, Z. Effects of fruit bagging on anthocyanins, sugars, organic acids, and colour properties of 'Granny Smith' and 'Golden Delicious' during fruit maturation. Eur. Food Res. Technol. 2013, 236, 329-339. [CrossRef]

65. Ritenour, M.; Schrader, L.; Kammereck, R.; Donahue, R.; Edwards, G. Bag and liner colour greatly affect apple temperature under full sunlight. Hortic. Sci. 1997, 32, 272-276.

66. Wang, L.; Zhang, X.; Liu, Y.; Shi, X.; Wang, Y.; Zhang, C.; Zhao, Z. The effect of fruit bagging on the colour, phenolic compounds and expression of the anthocyanin biosynthetic and regulatory genes on the 'Granny Smith' apples. Eur. Food Res. Technol. 2013, 237, 875-885. [CrossRef]

67. Huang, C.; Yu, B.; Teng, Y.; Sub, J.; Shu, Q.; Cheng, Z.; Zeng, L. Effects of fruit bagging on colouring and related physiology and qualities of red Chinese sand pears during fruit maturation. Sci. Hortic. 2009, 121, 149-158. [CrossRef]

68. Lin, J.; Chang, Y.; Yan, Z.; Li, X. Effects of bagging on the quality of pear fruit and pesticide residues. Acta Hortic. 2008, 772, 315-318.

69. Ding, P.; Syakirah, M.N. Influence of fruit bagging on postharvest quality of 'Harumanis' mango (Mangifera indica L.). Acta Hortic. 2010, 877, 169-174. [CrossRef]

70. Xie, R.J.; Zheng, L.; Jing, L.; He, S.L.; Xi, W.P.; Lu, Q.; Yi, S.L.; Zheng, Y.Q.; Deng, L. The effect of cultivar and bagging on physicochemical properties and anti-oxidant activity of three sweet orange cultivars (Citrus sinensis (L.) Osbeck). Am. Eurasian J. Agric. Environ. Sci. 2013, 13, 139-147.

71. Pisciotta, A.; Barbagallo, M.G.; Di Lorenzo, R.; Hunter, J.J. Anthocyanin variation in individual 'Shiraz' berries as affected by exposure and position on the rachis. Vitis 2013, 52, 111-115.

72. Ju, Z.G.; Liu, C.; Yuan, Y. Activities of chalcone synthase and UDPGal, flavonoid-3-O-glycosyltransferase in relation to anthocyanin synthesis in apple. Sci. Hortic. 1995, 63, 175-185. [CrossRef]

73. Ju, Z.G.; Yuan, Y.; Liu, C.; Xin, S. Relationships among phenylalanine ammonia-lyase activity, simple phenol concentrations and anthocyanin accumulation in apple. Sci. Hortic. 1995, 61, 215-266. [CrossRef]

74. Wei, J.M.; Qi, X.D.; Fan, C.H.; Zhao, Z.Y. The effect of double-paper bags on the skin pigment, fruit sugar and acidity of 'Red Fuji' apple. Chin. Agric. Sci. Bull. 2006, 22, 346-350.

75. Xia, J.; Zhang, Z.; Qu, S.C.; Xu, C.C.; Gao, J.J. Effects of bagging on the quality factors of Jiang Su 'Red Fuji' apple in the process of growth and development. Jiangsu J. Agric. Sci. 2009, 25, 351-356.

76. Jhons, G.C.; Scott, K.J. Delayed harvesting of bananas with "scaled" covers on bunches. 1. Modified atmosphere and microclimate inside sealed covers. Aust. J. Exp. Agric. 1989, 29, 719-726. [CrossRef]

77. Jhons, G.C.; Scott, K.J. Delayed harvesting of bananas with "scaled" covers on bunches. 2. Effect on fruit yield and quality. Aust. J. Exp. Agric. 1989, 29, 727-733. [CrossRef]

78. Saure, M.C. External control of anthocyanin formation in apple. Sci. Hortic. 1990, 42, 181-218. [CrossRef]

79. Cliff, M.A.; Dever, M.C.; Reynolds, A.G. Descriptive profiling of new and commercial British Columbia table grape cultivars. Am. J. Enol. Vitic. 1996, 47, 301-308.

80. Rolle, L.; Giacosa, S.; Gerbi, V.; Novello, V. Comparative study of texture properties, color characteristics and chemical composition of white table grape varieties. Am. J. Enol. Vitic. 2011, 62, 49-56. [CrossRef]

81. Rolle, L.; Siret, R.; Río Segade, S.; Maury, C.; Gerbi, V.; Jourjon, F. Instrumental texture analysis parameters as markers of table-grape and winegrape quality: A review. Am. J. Enol. Vitic. 2012, 63, 11-28. [CrossRef]

82. Rolle, L.; Giacosa, S.; Gerbi, V.; Bertolino, M.; Novello, V. Varietal Comparison of The Chemical, Physical, and Mechanical Properties of Five Colored Table Grapes. Int. J. Food Prop. 2013, 16, 598-612. [CrossRef]

83. Tunick, M.H. Food texture analysis in the 21st century. J. Agric. Food Chem. 2011, 59, 1477-1480. [CrossRef]

84. Giacosa, S.; Torchio, F.; Río Segade, S.; Giust, M.; Tomasi, D.; Gerbi, V.; Rolle, L. Selection of a mechanical property for flesh firmness of table grapes in accordance with an OIV ampelographic descriptor. Am. J. Enol. Vitic. 2014, 65, 206-214. [CrossRef]

85. Chen, L.; Opara, U.L. Texture measurement approaches in fresh and processed foods-A review. Food Res. Int. 2013, 51, 823-835. [CrossRef]

86. Fuentes, S.; Manso, A.; Fenoll, J.; Cava, J.; Garrido, I.; Molina, M.V.; Flores, P.; Hellín, P. Optimizing the methodology to measure firmness of grape berries (Vitis vinifera L.) during ripening. Acta Hortic. 2018, 1194, 1103-1110. [CrossRef]

87. Giacosa, S.; Zeppa, G.; Baiano, A.; Torchio, F.; Río Segade, S.; Gerbi, V.; Rolle, L. Assessment of sensory firmness and crunchiness of tablegrapes by acoustic and mechanical properties. Aust. J. Grape Wine Res. 2015, 21, 213-225. [CrossRef] 
88. Mencarelli, F.; Massantini, R.; Lanzarotta, L.; Botondi, R. Accurate detection of firmness and colour changes in the packing of table grapes with paper dividers. J. Hortic. Sci. 1994, 69, 299-304. [CrossRef]

89. Brown, K.; Sims, C.; Odabasi, A.; Bartoshuk, L.; Conner, P.; Gray, D. Consumer acceptability of fresh-market muscadine grapes. J. Food Sci. 2016, 81, 2808-2816. [CrossRef] [PubMed]

(C) 2020 by the authors. Licensee MDPI, Basel, Switzerland. This article is an open access article distributed under the terms and conditions of the Creative Commons Attribution (CC BY) license (http://creativecommons.org/licenses/by/4.0/). 